\title{
Renewal and reconstruction: Holy Writ in Ezra-Nehemiah - A missional reading
}

\author{
Author: \\ Bob Wielenga ${ }^{1}$ \\ Affiliation: \\ ${ }^{1}$ Gereformeerde Sending, \\ Richmond, KwaZulu-Natal, \\ South Africa \\ Correspondence to: \\ Bob Wielenga \\ Email: \\ wielenga@pmburg.co.za \\ Postal address: \\ PO Box 13229, Cascades \\ 3202, South Africa \\ Dates: \\ Received: 27 Jan. 2012 \\ Accepted: 05 July 2012 \\ Published: 10 May 2013 \\ How to cite this article: \\ Wielenga, B., 2013, 'Renewal \\ and reconstruction: Holy \\ Writ in Ezra-Nehemiah - A \\ missional reading', In die \\ Skriflig/In Luce Verbi 47(1), \\ Art. \#72, 9 pages. \\ http://dx.doi.org/10.4102/ \\ ids.v47i1.72

\section{Copyright:} \\ (C) 2013. The Authors. \\ Licensee: AOSIS \\ OpenJournals. This work \\ is licensed under the \\ Creative Commons \\ Attribution License.
}

Read online:
In this article we investigate the missional potential of the two-volume book of Ezra-Nehemiah We contend that the written word of God is a transforming power in society through the mediation of the church. This implies that spiritual renewal precedes social reconstruction. We examine this book historically, canonically and exegetically to lay a foundation for a missiological reflection on the results of this excursion in the field of biblical studies. We close with the formulation of some missional conclusions that serve as guidelines for the development of a relevant theology of mission.

Vernuwing en rekonstruksie: Heilige Skrif in Esra-Nehemia - 'n Missionêre lesing. In hierdie artikel ondersoek ons die missionêre moontlikhede van die tweedelige boek Esra-Nehemia. Ons stel dat die geskrewe woord van God 'n hervormende krag in die samelewing is deur die bemiddeling van die kerk. Dit impliseer dat geestelike vernuwing sosiale rekonstruksie voorafgaan. Ons doen historiese, kanoniese en eksegetiese ondersoek na die boek om 'n grondslag te lê vir 'n missiologiese beskouing van die resultate van hierdie ekskursie in die Bybelwetenskapveld. Ons sluit af met die formulering van missionêre gevolgtrekkings om te dien as wegwysers vir die ontwikkeling van 'n toepaslike sendingsteologie.

\section{Introduction}

In this article we want to probe the missional potential of the two-volume book of Ezra-Nehemiah (EN). ${ }^{1}$ At first glance the book seems to describe a postexilic, exclusivist community under threat of losing its ethnic identity in the Persian Empire. Its central notions of holiness, ritual purity and the policy of separation give the impression that the people closed ranks against a hostile world in order to survive as God's chosen people, his holy seed (Ezr 9:2) with their own language intact (Neh 13:23). The modern reader tends to discover here the beginnings of Jewish fundamentalism, with Jewish Zionism as its political heir (Wielenga 1990:258-291). Still, a close reading of the text shows that EN also has missional potential for our own times. We focus on one of three interrelated themes running through this book (Eskenazi 1988): the transforming power of God's written word, as contained in the 'book' of the Law of Moses, in renewing and restoring the postexilic community in the context of an oral, nonliterate culture. We therefore go into the orality-literacy debate with regard to Judah during the Second Temple period. We continue by summarizing the history of postexilic Judah, focusing on the role that Ezra and Nehemiah played in it. We then discuss the impact of God's written word, as contained in the 'book' of the Law of Moses, on the community of Jews returned from exile (golah). Having reflected on the outcome of our study missiologically, we will close with formulating some missional-relevant conclusions. ${ }^{2}$ In our deliberations we bear in mind that Ezra-Nehemiah played a role in the development of a theology of reconstruction in Southern Africa from the early 1990s onward (Villa-Vicencio 1992; Farisani 2002).

\section{The historical context}

\section{One book, two volumes}

We first have to clarify our understanding of EN as part of the canonical, Christian Bible with its kerygmatic unity centred in Jesus Christ (Wielenga 1992). We follow recent research (Eskenazi 1988:1-36), which treats EN as a literary unit on its own terms; not in isolation from Chronicles, but clearly distinct from it. In EN we find theologised historiography (Davies 1999:128; Eskenazi 1988:7). It is a literary construct, grown out of various traditions (Wright 2004), but it is nevertheless a structurally unified work through which three interlinked themes are running, one of which we are studying in this article (Eskenazi 1988:184; Grabbe 1998:93).

1.From here onward we use EN as abbreviation of the book Ezra-Nehemiah.

2.In this article we focus on the missional reading of EN. The New Testament and missiological sections do not receive a full treatment; they play a secondary role to form the background against which the missional potential of EN can be highlighted. 


\section{Judah after the exile}

It is important to realise that the Persian province of Judah (Yehud) contained a very reduced area after the exile, covering approximately 1700 square kilometres with at most 30000 inhabitants living in a radius of 15 kilometres around Jerusalem (Lipschits 2003:364). It was economically impoverished and dependent on foreign trade. Socially it was vulnerable with weak external boundaries. Politically and militarily it was firmly ruled top-down by the Persian administration and had to carry heavy tax burdens (Vanderhooft 2003:235-284; Berquist 2008:43). The return of the Jews from exile was in support of imperial policies. The restart of the temple-building project during the reign of Darius I (522-486 BC) was allowed in order to bolster the stability at its western border with rebellious Egypt (Berquist 1995:24, 110). The return of Ezra and Nehemiah during the reign of Artaxerxes I (465-442 BC) happened while Persia was campaigning against Egypt, which was assisted by Greece (Miller \& Hayes 1986:464). Their mission had to benefit above all Persian imperial interests. Let us note as well that there is no evidence in EN of Jewish insurgence on any level against the Persian overlords (cf. Horsley 2004:109-117). In EN, the golah used the space the Persian Empire allocated them for renewal and reconstruction of their own community according to their own convictions, while staying below the searching radar of their imperial overlords.

\section{Pre-exilic worldview}

It also needs to be noted that in postexilic Judah the pre-exilic worldview (Wielenga 2007:72), discredited by the 586 BC disaster, had to be renewed in line with the faith traditions of old. Fundamental expressions of faith (such as the invincibility of Jerusalem, the indestructability of the temple on Mount Zion, the lastingness of the Davidic monarchy and the unbreakable covenant relationship between a chosen nation and a God who was favouring her above all nations) had not survived the calamity of the exile. At the same time, instigated by exilic prophets like Deutero-Isaiah and Ezekiel, postexilic prophets like Trito-Isaiah, Haggai, Zecheriah and Malachi proclaimed the return of God to Zion, where he would be found again by the returned Jews and even by Gentile nations joining them in common worship. EN describes the reconstitution of a temple-centred community that is called to live a holy life according to the standards of Mosaic Law and that is separated from foreigners with their idolatrous influences. One of the hallmarks of the postexilic community is therefore its resistance to people who were suspected of idolatrous or, at best, syncretistic worship in spite of their ethnic kinship.

\section{Written words in an oral world}

Studying the impact of God's written word in postexilic Judah, we should have some idea of the nature of an ancient nonliterate society such as Judah was. Much study has been done concerning such oral cultures, including those in the ancient Near East (Ong 1982; Havelock 1986; Niditch 1996;
Van der Toorn 2007; Horsley 2007). We mention some of its characteristics.

\section{Scribal dominance}

In a society where only one per cent of the population before seventh century BC could read (Schniedewind 2004:98), the rise of a class of professional readers and writers is understandable. These scribes, trained in wisdom circles as advisers and administrators, and thoroughly familiar with the cultural and religious traditions of Israel (Horsley 2007:71-87), were mostly in the employment of the royal court (Schniedewind 2004:98) or the temple (Van der Toorn 2007:82). In particular, the Levitical scribes composed, copied, transmitted and explained the religious texts of the pre-exilic traditions. Written texts had a strong influence in an oral world, even if the people could not read those texts for themselves (Polaski 2007:37). In EN, royal decrees, imperial letters and administrative lists as written texts had absolute authority over the people and decided the course of postexilic history (Ska 2001:171).

\section{Authority of oral texts}

What Ong (1982) and Niditch (1996) write about the oral mode of written texts in nonliterate cultures is crucial for understanding the impact of God's written word in EN. Many of the texts found in the Torah were first orally composed and only later written down, but the oral origin of these written texts is still clearly evident. The voice of the one who spoke the texts in the first place was still discernible; its authority derived from the speaker behind the written words (Ong 1982:78). In Nehemiah 8 the people heard the voice of God speaking through the words read out to them. Of course, the writing down of oral traditions created a certain distance between the divine Speaker and his audience, which necessitated the intervention of temple scribes to read, translate and explain the divine message in the texts.

\section{Oral-aural community}

An important point, made by Ong (1982:72), is that the hearing of sound has a unifying, centralising and interiorising economy. Reading, based on seeing words, objectifies a text and makes its readers into separate individuals. Sight isolates; sound incorporates. Listening together to the presentation of oral or written traditions binds people in nonliterate cultures together into a community, as can be seen in Nehemiah 8 . Reading out loud from the 'book' of the Law of Moses received a unanimous response. The preservation of oral traditions can only be maintained in stable, homogeneous societies that are not in rapid change caused by crises (Ska 2001:173). In a crisis-ridden society like postexilic Judah's there is a need to textualise the oral traditions in order to provide an authoritative basis for the safeguarding of its identity, even if the people only had access to the text through the scribes.

\section{The crisis postexilic Judah suffered}

It is important to understand the crisis postexilic Judah suffered according to EN. First of all, we contend that this 
crisis was not of a socio-political or ethnic nature, but rather of a theological nature. ${ }^{3}$ It is surprising that EN pays scarcely, if at all, attention to the socio-political circumstances of the people on the ground, considering the realities of their situation (cf. Horsley 2008; Berquist 2008). The confrontation with the enemies from within and without is basically described as a spiritual one. Those socio-economic factors must have also played a role in this conflict (Wielenga 1990:76-85; Farisani 2002), but it does not show in the text. EN intentionally writes a depoliticised, spiritual-religious narrative about the postexilic community in line with the exilic prophecies of Deutero-Isaiah (Is 44:24-45:8) and Ezekiel (Ezk 40-48). In these prophecies the emphasis is on God's supreme power in history to fulfil his own plans with the representative remnant of Israel. The political events in general history are integrated in salvation history in theological fashion (Westermann 1969:154). EN is interpreting imperial history from a salvation historical perspective. We point out the following.

\section{No restoration of the monarchy}

In all probability, the Persian province of Judah (Yehud) was an own political unit with its own governors in the satrapy beyond the river (Rose 2000; Carter 1994). Governors, like Ezra and Nehemiah, were Persian loyalists, otherwise they would not have been able to exercise their power and to put their own programs into action. There is no evidence that the restoration of the Davidic monarchy was in view; the Davidic scion Zerubbabel disappears from the scene unnoticed (Rose 2000:33-36). Moreover, after the exile the future of the royal House of David was perceived as an eschatological ( $\mathrm{Hg} 2: 23)$ and not a political reality (Kessler 2002:63; 229).

\section{Syncretism the divisive factor}

Right from the beginning (Ezr 3:4; 4:1) the golah was met with resistance from enemies. These were excluded from joining them in rebuilding the temple and altar. Later on, in the time of Nehemiah, they were excluded from joining in the reconstruction of the city walls. Ethnically these enemies were partly related to the Judaeans, descending from the Northern tribes that were sent into exile in 722 BC by the Assyrians (2 Ki 17) and who remained in the land during the years of the Babylonian exile. It could be argued that many pre-exilic Judaeans also did not go into exile and remained behind, taking possession of the properties of their exiled compatriots (Wielenga 1990:76-85; Farisani 2002:188-190). They continued to worship in the ruined city during the exile, counselled by remaining Levites as their pastors (Wielenga 2007:71). Opponents of Nehemiah, like Tobiah and Sanballat, were ethnically linked with these non-exilic Israelites and Judaeans (Knoppers 2007:305-331) and were of Jahwistic orientation. Therefore, the leading opponents could, without much ado, marry into the families of the remigrants before the arrival of Ezra. The tensions between someone like Nehemiah and his opponents are not described in socio-political terms by EN, even if there should have been describing the crisis as an ethnic conflict between golah and the people left behind in Judah during exile. reasons for doing so. Only a theological reason is decisive in EN: they are perceived as ritually unclean; their professed adherence to the God of Israel is not accepted as genuine. Their allegiance to God is seen as mired in syncretism. Magen (2007:188) points out that a temple dedicated to the God of Israel was discovered on Mount Gerizim near Samaria. Sanballat I, governor of Samaria, built it in line with the pre-exilic traditions of Northern-Israel. ${ }^{4}$ EN singles out theological reasons for separating from their ethnically related kinsmen and others, which underscores its core message: the golah had to be a temple-centered, Torah-based community in Jerusalem dedicated to the God of the fathers in line with the pre-exilic faith traditions of old if they wanted to survive the postexilic situation with their God-given identity intact. However, EN did not completely exclude the ethnic Israelites and Judaeans who had remained behind in the land from joining the ranks of the golah. If they joined ranks with them spiritually, like prophets such as Obadiah and Haggai did (Van der Woude 1982; Raabe 1995), and supported the claims of the golah theologically, they were welcomed. They had to buy into the claim that the golah was the true Israel of God. ${ }^{5}$

\section{Servants of the Lord}

As far as the missions of Ezra and Nehemiah are concerned, we find the same intentional depoliticisation at work mentioned above. Both leaders were granted great political powers by their royal master with regard to stabilising the province in line with imperial interests of the time. But, in EN's presentation of the facts, neither Ezra nor Nehemiah seemed to have used those powers in solving the problems in Jerusalem. Eskenazi (1988:62) points out that in the crisis of mixed marriages with foreign women, Ezra is not the one to take the initiative, but the people themselves. Ezra plays a background role as intercessor in a religious-spiritual crisis; his contribution as specialist in Torah studies is stressed. Nehemiah, in comparison with Ezra, seemed to have been a much more forceful leader, using his authority as governor in the crises he faced (Neh $5 ; 13)$. But even he is depicted as a man not on a political mission in service of his royal master, but on a religious-spiritual one in service of his heavenly Lord. This is illuminated by his prayers, which intersperse the text of the narrative from beginning to end.

\section{The 'book' of the Law of Moses}

We concentrate on the 'book' of the Law of Moses, ${ }^{6}$ which Ezra took with him from Persia. We leave out the technical discussion about the question of whether or not this 'book' contained the Pentateuch as we find it today canonically in our modern Bibles. ${ }^{7}$ We contend that it is plausible that Ezra took a written version of the Law of Moses (Torah) with him

4.Becking $(2007: 213-222)$ cautions against too strong conclusions with regard to Sanballat I as temple builder, but the presence of this temple supports EN's contention that the opponents were not faithful to the pre-exilic faith traditions. Its resistance was not ideologically, but theologically informed.

5.See Isaiah 57:3-13; 65:1-7 for the influence of pre-exilic patterns of syncretism in postexilic Judah.

6.See Ezra 6:18; 7:14; Nehemiah 8:1,14, etc.

7.See Grabbe (2001); Horsley (2007); Williamson (1987); Ska (2001). 
to Jerusalem. It must have been a version not completely different from the one we are used to in our modern Bibles today. Variations between different versions are to be expected in an oral culture as Israel's was (Niditch 1996:95). Let us also realise that the use of the Torah in the postexilic situation was not based on a strict, literalistic interpretation of the written text. One did not quote written documents in ancient times, as we do today; they were used in recitation in public assemblies to communicate its message. Scribes recited the texts that they already knew by heart; trained as they were in memorizing the ancient, oral traditions (Horsley 2007:101). The 'book' of the Law of Moses was not there to be authoritatively quoted from. It was there as a witness to the authority of the orally transmitted traditions of the Law of Moses (Horsley 2007:98). One cited from memory the orally cultivated knowledge of the Torah. It is not possible to ascertain with absolute certainty from the canonical Pentateuch the exact identity of the 'book' of the Law of Moses, but we contend that our access to Ezra's Law of Moses through the canonical Pentateuch seems, all by all, to be reliable enough.

The emphasis on the written version of the Torah makes sense in the postexilic situation. In the crisis-ridden society of postexilic Judah there was a strong need for an authoritative, theological basis, built upon the faith traditions of old. Those could be found in the 'book' of the Law of Moses, the mediator of God's revelation on Mount Horeb, which bore the stamp of divine authority. The people received the written form of the Torah with reverence and fear (Neh 8). From Ezra's arrival onwards, the written Torah played a decisive role in the unfolding of the events, propelling history forward (Davies 1999:111; Eskenazi 1988:59, 88), even though the orally transmitted Torah traditions remained in use throughout the Second Temple period. It becomes the reference point for Israel's faith (Davies 1999:112). The postexilic community was structured by the authoritative word of God as textualised in Ezra's 'book' of the Law of Moses (Eskenazi 1988:96). The hallmark of belonging to the people of God from now on becomes obedience to the Law as taught in the Jerusalem temple by the Levitical scribes.

\section{The transforming power of God's written word}

\section{Parallels with the first exodus}

EN stresses the correspondence between the exodus from Egypt, as narrated in the Pentateuch, and the return from Babylon. Already in the royal decree of Cyrus (Ezr 1:4), edited by Jewish hands in the imperial office, we find a reference to Exodus 12:35. Just like the exodus generation was given the spoils of the Egyptians, so the golah generation was presented with the spoils of the Babylonians. That they, as first priority, rebuilt the altar and restarted the sacrificial ministry, reminds us of Moses' command to Joshua in Deuteronomy 27:1-8: to first build an altar after crossing into the promised land (Throntveit 1992:22). He also had to write the Law of Moses on big stone plates after the crossing of the Jordan (Miller
1990:190). In Ezra 3:2 the Law of Moses is mentioned as the driving force behind their actions. The parallel is intentional. For a new start it was imperative that God dwelled in their midst, which was possible only through sacrifices such as the burnt offerings (Lv 1;6). Their dependence on God's grace was affirmed in this way. Before the restoration of the community could commence, a spiritual renewal had to take place, ${ }^{8}$ which manifested itself in a renewed allegiance to the Law of Moses as well. God's word, as mediated by the Law of Moses, was the transforming force in the life of the golah. The restoration of the community depended on the renewal of the people around the altar and under the law, on grace and on obedience. This also led to the temple-rebuilding project in line with the prophecies of Ezekiel (37:26; 43:1-4; Wright 2001:327). ${ }^{9}$ But here, too, the Law of Moses (Ex 25-40) informed the people and propelled them towards the realisation of the first goal of the return: God dwelling again amongst His people out of love. Undoubtedly, it was the Law of Moses, as known through the oral traditions, which determined here the decisions of the golah. But it was the oral Torah, as authorised by the textualised version, which was later attested to by the 'book' of the Law of Moses, introduced by Ezra.

\section{Dissolution of mixed marriages}

\section{Theological context}

Another example of the transforming power of God's word is the infamous dissolution of mixed marriages during Ezra's and Nehemiah's stay in Jerusalem. ${ }^{10}$ We can only understand this dissolution, widely decried and denounced in scholarly literature, against the background of the temple theology dominant in the golah. With God in their midst, the people had to live lives purified from sin, which could separate them again from God and irrevocably terminate them as his chosen people. The external boundaries of the community had to be protected from foreign penetration. The many administrative lists in EN are a case in point (Janzen 2002:86). In his retelling of Israel's ancient history in Ezekiel 20:10-27 (Wright 2001:158), the prophet pointed out that God gave his Law so that his people would live (Lv 18:5; Dt 30:15-20). Not obeying could even lead to captivity (Lv 26:33). Interestingly enough, in Leviticus 26 there is a cause-effect relation between not keeping the Sabbaths and exile. In Nehemiah 13:15, Nehemiah has to intervene in the practice of trading on Sabbaths. Ezekiel's warning (Ezk 20:16) must have motivated Nehemiah's drastic measures against trading on the Sabbath. It is not the people's future as an ethnic unit that was so much at stake here (Blenkinsopp 1988:105; Throntveit 1992:25); its theological identity as chosen people was in danger, and so the threat of its extinction in a new exile was perceived as a real possibility. ${ }^{11}$

8.See Ezekiel 36:33; 47:1-14. Spiritual renewal, coming forth from a restored temple cult, had to precede inhabitation of the land (Wright 2001:356 ff., 365).

9. Halligan (2002:157) contends that the Second Temple was a textual reality; it was physically impossible to be built so early after the exile (2002:144-152).

10.For the ongoing discussion about this issue, see Janzen (2002; 2007); Smith-Christopher (1994); Davies (1999); Eskenazi \& Judd (1994).

11.See Isaiah 60:1 for a voice contemporary to EN (approximately $521 \mathrm{BC}$ ). This voice did not contradict EN, but complemented it from a different angle (Westermann 1969:295) 
We have to understand the dissolution of mixed marriages with foreign women against this background. It is unfortunate to compare the sending away of the foreign women with witch-hunts in the European Middle Ages (Janzen 2002:117; 2007:49-69). The theological reason for this harsh decision is then overlooked. Janzen, however, denies that the text refers to any theological reason as such. The foreign women are not accused of apostasy, or of leading their families to apostasy. In his opinion, the reference to Deuteronomy 7 and Exodus 34 is insufficient in spite of the deuteronomistic term detestable practices and the mentioning of the seven nations from which Israel had to be completely separated (Ezr 9:1). Following the arguments of anthropologist Mary Douglas, he contends that the women as foreigners should not have been admitted into the restored temple community at all. They were, per se, ontologically unclean and threatened as such the survival of the golah (Janzen 2007:62). These women were seen as sources of cultic impurity, even though they were not agents of impurity. The best protection of the community against the anger of a holy God is to remove the source of impurity - the foreign women and their children who were sent away as scapegoats. This reason for the dissolution of the mixed marriages is not mentioned in the text of EN, but Janzen contends that it is given with the concept of the holiness and cultic purity that operated in postexilic Judah (following the definition of the concepts given by Douglas). ${ }^{12}$ Other reasons for the dissolution have been given, but all are controversial: on either an economic, ethnic or racial level. In line with the theological thrust of EN, we should take the transforming power of God's written word more seriously, as it was orally communicated to the golah by the Levitical scribes and backed up by Ezra's 'book' of the Torah. We retain the theological explanation.

\section{Commitment to God's word}

From Ezra's homiletical prayer (Ezr 9:6-15; Davies 1999:61) it can be concluded that mixed marriages were seen as a serious offence against God's holiness. The special position of the golah (Ezr 9:8), in conjunction with the theological description of the community as holy seed (Ezr 9:2, cf. Ex 19:6; Jr 23:3), did not agree with mixed marriages with foreign women. The qualification of this practice as detestable $\left(m a^{\prime} a l\right)^{13}$ is deuteronomistic. The tradition-fixed number of the seven nations (Ezr 9:1) from which Israel had to be separated after crossing into the promised land (Dt 7:3-6, cf. Jos 23:12; Ex 33:2; 34:11; Throntveit 1992:56; Miller 1990:110), evoked memories of the stiff penalties in the golah that would follow them if they break the covenant God made with Israel on Mount Horeb (Dt 28:15). The pre-exilic faith traditions, as contained in Ezra's 'book' of the Law of Moses, had to be kept if the golah wanted to survive in the Persian Empire with their theological identity intact. EN does not only refer to ethnically foreign women. In pre-exilic Israel marrying nonIsraelite women was not completely forbidden; a noticeable 12.See Haber (2008:13-15) for a critique of Douglas' approach.

13. See Milgrom (1991:359) for a discussion of the technical term ma'al in Ezra 9:11 and 10:17. example is Moses himself marrying an African wife (Nm 12:1, cf. Dt 23:3-8). The Law of Moses informed the people here (Dt 20:17). It was not about racial purity, but about spiritual integrity in the relationship with the holy God who was again dwelling amongst them in Zion. Foreign women were those who did not follow their husbands in their faith and who did not share their new community's claims of representing the true Israel of God. Either they kept to their own religious traditions, or they rejected the exclusive Jahwistic claims of Ezra and his small band of God fearers (Ezr 9:4). Either way, they lived in conflict with God's revealed will that was made known through the oral Torah traditions and mediated to them by the Levitical scribes, and which were attested to by the 'book' of the Law of Moses, God's written word. In an oral culture this is a most dangerous thing to do (Miller 1990:161). Nehemiah 13:23 supports this interpretation. The non-Jewish women did not even make the effort to learn the language of their new community; it seemed to them not to be worthwhile to do so. In this way they excluded themselves from the language of faith in which the Torah was written (Kottsieper 2007:101). This would have had its impact on the children, who are especially mentioned. It would imply a break in the covenantal future of the golah. Even though the number of mixed marriages was actually not high (Ezr 10:18-43) the practice was deeply rooted in the upper classes of society, amongst which were the priests, and 20 years later it still persisted (Neh 13:23). In spite of the assistance he received from especially the God-fearers, ${ }^{14}$ Ezra's reform did not gather enough support needed for the drastic action of sending away foreign wives and their children (Ezr 9:15). From whichever perspective we look at the decision, it is harsh, and even repulsive for modern readers of the narrative. For EN it is evidence of the transforming power of God's word in the postexilic community of faith, orally communicated to them and authoritatively attested to by Ezra's 'book' of the Law of Moses.

\section{Conclusion}

At last, we have to notice that the reading from the 'book' of the Law of Moses (Neh 8) had a powerful impact on the assembled golah. It created a spirit of mourning and repenting amongst them (Neh 9) and it led to the renewal of the covenant (Neh 10). Only then the reconstruction of society started with the repopulation of Jerusalem and the dedication of the wall (Neh 11-12). No social reconstruction is possible without spiritual renewal first.

\section{Canonical considerations}

In the Christian Bible, the Old and New Testaments are canonically and thematically interlinked (Wielenga 1992; Wright 2006). We therefore follow the trajectory of our theme from the Old Testament into the New Testament. How did it impact on the life of church and society? Considerations of space restrict us to sketching only the main lines of the argument.

14.For more about the God-fearers trembling for the word of God in Isaiah $66: 2,5$ see Westermann (1969:413). 


\section{God's word in the New Testament}

In the New Testament it is clear that the Old Testament in its written form and in its Greek translation (the LXX) functioned as the authoritative word of God for Jesus and his disciples. Of course, one knew the writings of Tenakh not by reading it for oneself, but by hearing it recited by scribes in the temple or the synagogues. Also, Jesus must have known Scripture from hearing it recited and learning it by heart. From that source of intimate knowledge, Christologically understood (Ellis 2001:80-92), he taught his disciples and it transformed them (Lk 24:14). Right from the beginning, the words of Jesus were cultivated and orally transmitted and cited as the authoritative word of God (Lk 1:2; 1 Cor 15:1). The same happened to apostolic teachings (Jude 17). These orally transmitted traditions were still referred to as divine word until the second century AD. But from that time onward the written versions of these traditions together with, for instance, the Letters of Paul (written from the onset), took the place of the oral versions as the authoritative word of God. From the fourth century AD, the New Testament writings were available in one codex, which stimulated the canonization process of the New Testament (Aichele 2001:43). The written word of God as book in canonical form also suggests that it conveys a unified message; a grand narrative (Aichele 2001:49) that originated from a first, divine speaker (Wielenga 2010). Just as the golah had an existential need after the exile for an authoritative version of the Law of Moses, so in the doctrinal turmoil of the fourth century AD (Greschat 1984), the church needed a reliable source of Scriptural authority to sort out its doctrinal differences, which rented the church apart. The influence of Scripture on the nonliterate ordinary church members was facilitated through it being recited, preached and taught from the pulpit (Graham 1987:126-135). The oral functioning of Scripture, even in its printed form, was dominant in the Western church until the typographical culture inaugurated a new relationship with Scripture in the nineteenth century AD (Graham 1987:19, 45, 165).

\section{The message communicated}

A central topic in EN was God's return to Jerusalem to dwell in the temple on Mount Zion, amongst his people reconstituted as the true Israel and whose life was authoritatively guided by the Torah. We want to point out that this is also the message of the New Testament Scripture. We summarise it as follows.

\section{Jesus, the new temple}

The temple as God's dwelling place became obsolete, because God was pleased to have all his fullness dwell in Jesus, who is God with us; Immanuel (Col 1:19; Mt 1:23; Is 7:14). The sacrificial ministry in the temple was replaced once for all by the substitutionary sacrifice of Jesus on the cross (Heb 7-10). Around him, risen and ascended into heaven, an alternative Spirit-driven community came into being that was based upon the teachings of apostles and prophets, and followed him as Lord under the operation of the Spirit (Ac 2-4). Peter described this community as a holy nation and a kingdom of priests (1 Pt 2:9; Ex 19:6). This community's theological, and not ethnic, identity was crucial. Gentiles were welcomed to the fellowship of God's people against the violent opposition of Jews and Jewish-Christians, who continued in the footsteps of post-EN traditions of the intertestamental period. In line with the Old Testament, the New Testament does not perceive the separation between the church and the surrounding world in ethnic terms, but rather in theological terms. The holiness of the church is related to her Lord, Jesus Christ. It is set apart by him to serve him in his mission to the world. Holiness is also a moral concept, referring to obedience to all that Jesus has commanded (Mt 28:20). It should distinguish the church from the world and make it into an alternative community. The Christian community should be visibly holy and so spread light in darkness (Mt 5:14-16; Is 60:1). The New Testament endorses the message of $\mathrm{EN}$ in this respect.

\section{In the shadow of Rome}

In the early Christian church, just as in EN, we also do not see signs of direct opposition against the Roman Empire in the public domain. Jesus himself did not engage in confrontational action with the imperial institutions during his lifetime, and was not aggressively opposing the imperial authorities (Carter 2008:128). He was not seen as politically dangerous to Rome as many other political activists in those days were (Den Boeft \& Van Poll-Van De Lisdonk 1999). His execution as a revolutionary was politically expedient. This is not to say that his message was without consequences in the public domain of the Roman Empire. The persecution of the church, caused by the Christian refusal to worship the emperor, was a reaction to the threat experienced to the political stability of the Roman Empire. The new movement was vulnerable and with weak external boundaries; constantly penetrated by foreign influences, be it Jewish or gentile. In the Apostolic Letters the holiness of the faith community as the people of God, the body of Christ and the temple of the Holy Spirit, is stressed time and again. Paul warned against syncretism (1 Cor $8 ; 10)$ and he discouraged marrying outside of the faith (1 Cor 7$)$. In his first letter, Peter encouraged the scattered and exiled believers of his churches to stand firm and referred to the protective work of the Triune God amongst them (1 Pt 1:2). He recommended suffering for the sake of Christ, if needed (1 Pt 4:12). It is clear that the Christian churches addressed in the Letters were living on the margins of the Roman Empire without political power or influence and persecuted by the Jews, and later also by the Romans. In spite of their depoliticised message and non-aggressive stance in the public domain (Mt 5:38), culminating in the call to obey the powers that be (Rm 13:1; $1 \mathrm{Pt} 2: 13)$, they were perceived as a danger to the security of the Empire. Jesus' teachings did indeed intend to impact the public domain of the Roman Empire, but it had to happen through making disciples of all nations (Mt 28:18-19), as well as the exemplary life of the church as alternative community, as we find it spelled out in the Sermon on the Mount (Mt 5-7) or in Matthew 25:31-46. Yoder (1998:80-95; cf. Bosch 1982) ${ }^{15}$ refers, amongst other things, to the nonconformity of Christian

15.See De Bruijne (2011:370) for a Reformed approval of the Anabaptist approach towards the relationship between church and society; and for a critique see De Bruijne (2011:380). 
discipleship expressed in serving love, even at the cost of personal wellbeing, seeking reconciliation between people in the face of adversity, the willingness to be cross-bearers in the footsteps of Jesus (Jn 15:20), and seeking to discern the signs of the time prophetically (1 Jn 4:1).

\section{Missiological reflections}

In this section we want to reflect missiologically on the results of our close reading of EN in the light of the New Testament. Two interlinked themes will be studied: the relationship between church and society, and the transforming power of the written word of God, the Bible, in the life of the church and subsequently in society.

\section{The church between separation and participation}

The church is in the world, but not of the world. This wellknown Johannine saying (Jn 17:14) concisely formulates the theme under investigation (Bosch 1991:385). It assumes that the church has not just a temporal, but also an eschatological horizon. In the present era, the church anticipates the promised new world in which it already participates (Volf 1998:139, 150, 267). This presumes a tension between the church and its environment, cultural and socio-political. The church should therefore not be absorbed in its historical context and become a national or an ethnic church and so losing its distance to and distinctiveness from its surroundings. But it should not be separated from it either (Bosch 1991:388) as it is being called to participate in the lives of the nations and their people (Mt 28:18). In missiological terms, the church should maintain the tension between contextualisation and syncretism. This tension is also reflected in its organisation. It is organised along the social patterns that can be found in a given society at a given time, but at the same time, it is the Spirit-driven community of Christ-confessing believers who live from God's love mediated through the means of grace (word and sacraments). The church is therefore a celebrating, hearing and praying community living off its worship services. But worship should manifest itself in the day-to-day living reality of Christian service in the midst of society. This translates itself into a biblically transformed lifestyle, which may be different from that of their fellow citizens (Eph 4:20).

In EN and the New Testament we receive the same message: separation is a given in being the people of God, the church of Jesus Christ, who are following in his footsteps as Lord. It is a non-negotiable part of its being in the world, but for the sake of the world (Bosch 1991:385). This message of EN is also relevant in our times. The postexilic community had to protect her theological identity, which was granted to her by a merciful God. In the shadow of the Persian Empire it had no choice but to firmly guard her external boundaries in order to survive into the future as a recognisable religious entity with its spiritual integrity intact. Against the background of the grand narrative of the entire canonical word of God, this stance was not separatist or isolationist; it was of a missional necessity. This is confirmed by the New Testament writings. The church is called out of the world to be simultaneously sent into the world. Without the preservation of its identity, its missional potential cannot be activated (De Bruijne 2011:383). But an introverted church, isolated from the world, has squandered its missionary mandate.

\section{The transforming power of God's written word}

This brings us to the second leg of our investigation in the missional potential of EN. Our question now is: how is God's written word a transforming power in society with its reconstruction as one of its fruits? It is our contention that the Spirit-driven church is called to mediate this word to the world. The transforming power of the Bible, under the operation of the Holy Spirit, should be manifested in the church as an alternative community before it can be expected to transform any structure operational in society. In EN the 'book' of the Law of Moses given to Israel had a transforming impact on the golah, and not on the Persian Empire in the first place. The Christian Bible, given to the church as the people of God, was initially a transforming power in the early church; not in the Roman Empire. The written word of God transformed the Roman Empire only in a very slow, historical process through the mediation of a transformed church after the Pentecost. Every reformation or revival in church history commenced with a new discovery of the relevance of the Bible for the people of God in their own context. This resulted in a transformed worldview within the church, which stimulated her to reach out into the world. And so it had an impact beyond the church. The impact of the Bible in the vernacular on colonial Africa is a clear example of this principle (Bediako 1995:54, 123).

In the early church, located in an oral culture as postexilic Judah was, the apostles and their successors played a central role in facilitating the authoritative teachings of Scripture, which transformed the lives of the individuals and communities under the operation of the Holy Spirit. They were called to serve the church as teachers of God's word (1 Cor 12:29; cf. Wielenga 2010:709-712, 715; Volf 1998:246).

\section{Missionial conclusions}

We conclude with the following statements to guide us in the formulation of missional theories of reconstruction in a theology of missions:

- The church, being a fruit of hearing of God's written word under the operation of the Holy Spirit, is God's missionary agent on earth. This community is dimensionally involved in God's mission by guarding its theological identity as the people of God, the body of Christ and the temple of the Spirit. Through its holiness, reflected in its liturgically structured worship and its alternative lifestyle, it attracts the world centripetally. Simultaneously, the church is also intentionally involved in God's mission by centrifugally going out into the world in order to proclaim the message of the Gospel, living it sacrificially and following its Lord in the service of the coming Kingdom. ${ }^{16}$ This corresponds with EN's emphasis on the protection of the external

16.For the terms dimensional, intentional, centripetal and centrifugal, see Bosch (1979 79-83; 199). 
boundaries of the golah and of its theological identity, but it is now functioning within the New Testament framework of worldwide mission.

- The power of God's written word transforms society indirectly through the agency of the church, which is being renewed daily by the Spirit with and through that word. In this renewal process, the Bibleteaching ministry of the church plays a facilitating role. The Bible is given first to the church as God's people, through whom it has to impact on society and the wider world. This corresponds with EN's emphasis on the role of the scribal class in the communication of God's written word. This forms the material basis for the New Testament teaching that faith comes from hearing the message as contained in God's written word.

- The role of the church as an agent of change in society must not be overrated, which is still operating as it does on this side of history. Its internal renewal and ongoing transformation is often too open for serious critique from within and without, which discredits its attempts to reach out to the world and compromises its contributions to the reconstruction of society. Where possible, the church contributes in all humility to its Lord's mission to the world. Because of its Lord, it does so in all boldness. This corresponds with EN's emphasis on the golah's failure to protect its external boundaries and its theological identity. In the New Testament teachings this failure is seen as an impediment to the world mission.

\section{Acknowledgements \\ Competing interests}

The author declares that he has no financial or personal relationship(s) that may have inappropriately influenced him in writing this paper.

\section{References}

Aichele, G., 2001, The control of biblical meaning: Canon as semiotic mechanism, Trinity Press International, Harrisburg, PA.

Becking, B., 2007, 'Do the earliest Samaritan inscriptions already indicate a parting of the ways?' in O. Lipschits, G.N. Knoppers \& R. Alberts (eds.), Judah and the Judaean in the fourth century BCE, pp. 213-222, Eisenbraun, Winona Lake.

Bediako, K., 1995, Christianity in Africa: The renewal of a non-Western religion, Edinburg University Press, Edinburg.

Berquist, J.L., 1995, Judaism in Persia's shadow: A social and historical approach, Fortress Press, Minneapolis.

Berquist, J.L., 2008, 'Resistance and accommodation in the Persian Empire', in R.A. Horsley (ed.), In the shadow of empire: Reclaiming the Bible as a history of faithful resistance, pp. 41-58, Westminster John Knox Press, Louisville-London.

Blenkinsopp, J., 1988, Ezra-Nehemiah, SCM Press, OTL, London.

Bosch, D.J., 1979, Heil vir die wêreld: Die Christelike sending in teologiese perspektief N.G. Kerkboekhandel, Pretoria.

Bosch, D.J., 1982, The church as alternative community, Instituut vir Reformatoriese Studies, Potchefstroom.

Bosch, D.J., 1991, Transforming mission: Paradigm shifts in theology of mission, Orbis Books, Maryknoll.

Brett, M.G. (ed.), 1996, Ethnicity and the Bible. Biblical Interpretation Series 19, Brill, Leiden.

Carter, C.E., 1994, 'The province of Yehud in the post-exilic period: soundings in the site distribution and demography', in T.C. Eskenazi \& K.H. Richards (eds.), Second Temple Studies Vol. 2: Temple community in the Persian period, pp. 106-145, JSOT Press, Sheffield.

Carter, W., 2008, 'Matthew negotiates the Roman empire', in R.A. Horsley (ed.), In the shadow of empire: Reclaiming the Bible as a history of faithful resistance, pp.117-137, Westminster John Knox Press, Louisville-London.
Davies, G.F., 1999, Ezra and Nehemiah, The Liturgical Press, Collegeville, Minnesota.

De Bruijne, A.L.Th., 2011, 'Niet van deze wereld. De hedendaagse Gereformeerde publieke theologie en de "doperse optie"', Theologie Reformata 54(4), 366-390.

Den Boeft, J. \& Van Poll-Van De Lisdonk, M.L. (eds.), 1999, The impact of Scripture in early Christianity (Supplements to Vigiliae Christianae, XLIV), Brill, Leiden.

Ellis, E.E., 2001, 'Uitleg van het Oude Testament in het Nieuwe Testament', in E. Eynickel, E. Noort, T. Baarda \& A. Denaux (eds.), Internationaal Commentaar op de Bijbel, pp. 80-92, Kok / Averbode, Kampen.

Eskenazi, T.C., 1988, In an age of prose: A literary approach to Ezra-Nehemiah, Scholars Press, Atlanta.

Eskenazi, T.C. \& Judd, E.P., 1994, 'Marriage to a stranger in Ezra 9-10', in T.C. Eskenazi \& K.H. Richards (eds.), Second Temple Studies, Vol. 2: Temple community in the Persian period, pp. 266-285, JSOT Press, Sheffield.

Farisani, E.B., 2002, 'The use of Ezra-Nehemiah in a quest for theology of renewal, transformation and reconstruction in the (South) African context', PhD thesis, University of KwaZulu-Natal, Pietermaritzburg.

Grabbe, L.L., 1998, Ezra-Nehemiah, Routledge, London/New York.

Grabbe, L.L., 2001, 'The law of Moses in the Ezra tradition: more virtual than real?', in J. Watts (ed.), Persia and Torah: The theory of imperial authorization of the Pentateuch, pp. 91-114, Society of Biblical Literature, Atlanta.

Graham, W.A., 1987, Beyond the written word: Oral aspects of Scripture in the history of religion, Cambridge University Press, Cambridge.

Greschat, M. (ed.), 1984, Gestalten der Kirchengeschichte. Alte Kirche I \& II, Kohlhammer, Stuttgart.

Haber, S., 2008, 'They shall purify themselves': Essays on purity in early Judaism, Society of Biblical Literature, Atlanta.

Halligan, J., 2002, 'Unsolved mysteries: the Second Temple', in A.C. Hunter \& P.R. Davies (eds.), Sense and sensitivity: Essays on reading the Bible in memory of Robert Carroll, pp. 142-158, JSOT Press, Sheffield.

Havelock, E., 1986, The muse learns to write: Reflections on orality and literacy from antiquity till the present, Yale University Press, New Haven, London.

Horsley, R.A., 2004, 'The origin of the Hebrew Scriptures in imperial relations', in J.A. Draper (ed.), Orality, literacy and colonialism in antiquity, pp. 107-134, Brill, Leiden/Boston.

Horsley, R.A., 2007, Scribes, visionaries, and the politics of Second Temple Judea, Westminster John Knox Press, Louisville/London.

Horsley, R.A. (ed.), 2008, In the shadow of empire: Reclaiming the Bible as a history of faithful resistance, Westminster John Knox Press, Louisville/London.

Janzen, D., 2002, Witch-hunts, purity and social boundaries: The expulsion of the foreign women in Ezra 9-10, Sheffield Academic Press, Sheffield.

Janzen, D., 2007, 'Scholars, witches, ideologues and what the text said: Ezra 9-10 and its interpretation', in J.L. Berquist (ed.), Approaching Yehud: New approaches to the study of the Persian period, pp. 49-69, Society of Biblical Literature, Atlanta.

Kessler, J., 2002, The book of Haggai. Prophecy and society in early Persian Yehud (Vetus Testamentum 91), Brill, Leiden.

Knoppers, G.N., 2007, 'Nehemiah and Sanballat: the enemy without or within?', in O. Lipschits, G.N. Knoppers \& R. Alberts (eds.), Judah and the Judaeans in the fourth century BCE, pp. 305-331, Eisenbrauns, Winona Lake.

Kottsieper, I., 2007, "'And they did not care to speak Yehudit": on linguistic change in Judah during the late Persian era', in O. Lipschits, G.N. Knoppers \& R. Alberts (eds.), Judah and the Judaeans in the fourth century BCE, pp. 95-124, Eisenbrauns, Winona Lake.

Lipschits, O., 2003, 'Demographic changes in Judah between the seventh and fifth centuries BCE', in O. Lipschits \& J. Blenkinsopp (eds.), Judah and the Judaeans in the Neo-Babylonian period, pp. 323-376, Eisenbrauns, Winona Lake.

Magen, Y., 2007, 'The dating of the first phase of the Samaritan temple on Mount Gerizim in the light of the archaeological evidence', in O. Lipschits, G.N. Knoppers $\&$ R. Alberts (eds.), Judah and the Judaeans in the fourth century BCE, pp. 157-211, Eisenbrauns, Winona Lake.

Milgrom, J., 1991, Leviticus 1-16. Anchor Bible, Doubleday, New York.

Miller, P.D., 1990, Deuteronomy. Interpretation, John Knox Press, Louisville.

Miller, J.M. \& Hayes, J.H., 1986, A history of ancient Israel and Judah, SCM Press, London.

Niditch, S., 1996, Oral world and written word: Ancient Israelite literature, Westminster John Knox Press, Louisville.

Ong, W., 1982, Orality and literacy: The technologizing of the word, Methuen, London/ New York. http://dx.doi.org/10.4324/9780203328064

Polaski, D.C., 2007, 'What mean these stones? Inscriptions, textuality and power in Persia and Yehud', in J.L. Berquist (ed.), Approaching Yehud: New approaches to the study of the Persian period, pp. 37-48, Society Biblical Literature, Atlanta.

Raabe, P.R., 1995, Obadiah. Anchor Bible, Doubleday, New York.

Rose, W., 2000, Zemah and Zerubabel: Messianic expectations in the early post-exilic period, Sheffield Academic Press, Sheffield.

Schniedewind, W.M., 2004, How the Bible became a book? The textualisation of ancient Israel, Cambridge University Press, Cambridge.

Ska, J.L., 2001, 'Persian imperial authorization: some question marks', in J. Watts (ed.), Persia and Torah: The theory of imperial authorization of the Pentateuch, pp. 161-182, Society of Biblical Literature, Atlanta. 
Smith-Christopher, D.L., 1994, 'The mixed marriage crisis in Ezra 9-10 and Nehemiah 13: A study of the sociology of the post-exilic Judaean community', in T.C. Eskenazi
$\&$ K.H. Richards (eds.), Second Temple Studies, Vol. 2: Temple community in the $\&$ K.H. Richards (eds.), Second Temple Studies, Vol.
Persian period, pp. 243-265, JSOT Press, Sheffield.

Smith-Christopher, D.L., 1996, 'Between Ezra and Isaiah: exclusion, transformation and inclusion of the "foreigner" in post-exilic biblical theology', in M.G. Brett (ed.) Ethnicity and the Bible, pp. 117-142, Brill, Leiden.

Throntveit, M., 1992, Ezra-Nehemiah. Interpretation, John Knox Press, Louisville.

Vanderhooft, D., 2003, 'Babylonian strategies of imperial control in the West: royal practice and rhetoric', in O. Lipschits, G.N. Knoppers \& R. Alberts (eds.), Judah and the Judaeans in the Neo-Babylonian period, pp. 235-262, Eisenbrauns, Winona Lake.

Van der Toorn, K., 2007, Scribal culture and the making of the Hebrew Bible, Harvard University Press, Cambridge.

Van der Woude, A.S., 1982, Haggai-Maleachi. De Prediking van het Oude Testament, Callenbach, Nijkerk.

Villa-Vicencio, C., 1992, A theology of reconstruction, David Philip, Cape Town. http:// dx.doi.org/10.1017/CBO9780511607592

Volf, M., 1998, After our likeness: The church as the image of the trinity, Eerdmans, Grand Rapids.
Westermann, C., 1969, Isaiah 40-66, The Westminster Press, Philadelphia.

Wielenga, B., 1990, "'Volk van het land" als missiologisch model: Oude Testament en zending in Zuidafrikaanse kontekst', DTh thesis, Unisa, Pretoria.

Wielenga, B., 1992, 'The Bible in a changing South Africa: The quest for a responsible, biblical hermeneutic in mission', Missionalia 20(1), 28-37. http://dx.doi.org/10.4102/ ids.v41i1.296

Wielenga, B., 2007, 'The suffering witness: A missiological reading of Lamentations', In die Skriflig 41(1), 69-86.

Wielenga, B., 2010, 'Bible reading in Africa - the shaping of a reformed perspective', In die Skriflig 44(3\&4), 699-721.

Williamson, H.G.M., 1987, Ezra-Nehemiah, JSOT Press, Sheffield.

Wright, C.H.J., 2001, The message of Ezekiel, Inter-Varsity Press, Leicester. http://dx.doi. org/10.1515/9783110927207

Wright, J.L., 2004, Rebuilding identity: The Nehemiah-memoir and its earliest readers, De Gruyter, Berlin/New York.

Wright, C.H.J., 2006, The mission of God: Unlocking the Bible's grand narrative, IVP Academic, Downers Grove, Illinois.

Yoder, J.H., 1998, The royal priesthood: Essays ecclesiastical and ecumenical, Herald Press, Scottdale, PA. 